\title{
Development of Integrated Teachings of Al-Qur'an Verses in Class I Students in Elementary Schools
}

\section{Pengembangan Bahan Ajar Terintegrasi Ayat-Ayat Al-Qur'an Pada Peserta Didik Kelas I Di Sekolah Dasar}

\author{
Mutmainna \\ Fakultas Tarbiyah dan Ilmu Keguruan \\ Institut Agama Islam Negeri (IAIN) Palopo \\ Email : mutmainna816@gmail.com
}

\author{
How to cite this article: \\ Mutmainna. (2020). Development Of Integrated Teachings Of Al-Qur'an Verses In Class \\ I Students In Elementary Schools. Pedagogik Journal of Islamic Elementary School, \\ 3(1), 47-62. https://doi.org/10.24256/pijies.v3i2.1288
}

\begin{abstract}
The purpose of this study was to develop a prototype of integrated five-senses teaching material in the verses of the Qur'an in class I students at SDN 01 Lalebbata Palopo, and to find out the level of effectiveness of teaching materials developed towards the learning outcomes of class students I at SDN 01 Lalebbata Palopo. Research \& Development is the research method used. To develop products, this study uses a 4-D development model consisting of four stages, namely: (1) Define, (2) Design, (3) Develop, and (4) Disseminate. Data collection techniques used are documentation, observation, and validation. The data analysis technique used by the researcher was to test its validity by using the Aiken's formula and observation using descriptive statistical analysis. By the results of the validation, the integrated five-sensory material module with the verses of the Qur'an is said to be valid because it obtains an average validation result of 0.67 where the value is included in the valid category in terms of all aspects of the module. This module is said to be effective using the student activity observation sheet, where the results of the observation sheet which is $93.10 \%$ fall into the very good category.
\end{abstract}

Keywords: Al Qur'an verses; Primary School; Teaching material development

\begin{abstract}
Abstrak
Tujuan penelitian ini untuk mengembangkan prototipe bahan ajar materi panca indera terintegrasi ayat-ayat Al-qur'an pada peserta didik kelas I di SDN 01 Lalebbata Palopo yang valid, dan untuk mengetahui tingkat keefektifan bahan ajar yang dikembangkan terhadap hasil belajar peserta didik kelas I di SDN 01 Lalebbata Palopo. Metode penelitian yang digunakan yaitu Research \& Development. Untuk mengembangkan produk, penelitian ini menggunakan model pengembangan 4-D yang terdiri dari empat tahap yaitu: (1) Define, (2) Design, (3) Develop, dan (4) Disseminate. Teknik pengumpulan data
\end{abstract}


yang digunakan adalah: dokumentasi, observasi dan validasi. Teknik analisis data yang digunakan peneliti itu untuk menguji kevalidannya yaitu menggunakan rumus Aiken's dan observasi menggunakan analisis statistik deksriptif. Sesuai dengan hasil validasi, modul materi panca indera terintegrasi dengan ayat-ayat Alqur'an dikatakan valid karena memperoleh hasil validasi rata-rata 0,67 dimana nilai tersebut termasuk dalam kategori valid yang ditinjau dari keseluruhan aspek modul. Modul ini dikatakan efektif dengan menggunakan lembar observasi aktivitas peserta didik, dimana hasil dari lembar observasi yaitu 93,10\% masuk dalam kategori sangat baik.

Kata kunci: Ayat-Ayat Al qur'an; Pengembangan bahan ajar; Sekolah dasar

(OPedagogik Journal of Islamic Elementary School. This is an open access article under the Creative Commons - Attribution-ShareAlike 4.0 International license (CC BY-SA 4.0)

\section{Introduction}

Based on the National Education System Law (SISDIKNAS) No. 20 of 2003, education is something that is planned to realize the goals of education by creating active learning in exploring the potential of students in matters of religion, noble character, self-control, personality, skills, intelligence that is useful for the environment (Indonesia, 2003). Education is a learning activity both indirectly and directly for the realization of educational goals.

Supporting factors for educational success is an educator. Educators are required to be more creative and innovative in the learning process such as developing teaching materials so that learning objectives can be achieved (Aprilia, 2018). But in general, teachers use government circular textbooks as the main teaching material and even not infrequently as the only teaching material as a reference for student learning. Teaching material is a printed and non-printed learning tool that is needed by an educator to improve the learning process (Daryanto \& Aris, 2014). The principles used in selecting teaching materials are relevance, consistency, and adequacy (Hamid, 2012).

Based on the results of observations by researchers on Wednesday, April 4, 2018, at SDN 01 Lalebbata Palopo. First, the learning outcomes of class I sensing material that explains that $10 \%$ of students are unable to get a value of 70 according to the KKM that has been set. Secondly, the science module on the five-sensory material that is integrated with Alqu'an verses is not yet available, where the teaching material used by the teacher to deliver the five-sensory material still sticks to the printed book without any renewal of the teaching material. 
In this study, researchers will develop one of the teaching materials, namely modules. Modules are types of teaching materials that are arranged systematically so that they can be used by students independently consisting of methods, evaluations, and material content (Setyowati, Parmin, \& Widiyatmoko, 2013). The use of teaching materials in the form of modules can make students play an active role in learning such as opening, reading, taking notes, and giving a sign on teaching materials in the form of modules showing active and effective teaching and learning activities (Parmin \& Peniati, 2012).

There are several characteristics of the module, namely: stand-alone, selfcontained, self-instruction, adaptive, and user friendly (Arum \& Wahyudi, 2016). Some module components are explicit and specific instructional goal formulation, instructions for using the module, student activity sheets, worksheet keys, evaluation sheets, and evaluation sheet keys (Lady, 2013). The module that the researcher will develop is the science learning module. Natural science (IPA) is an observation in the form of objects made by humans to know and understand the universe by following the steps and using reasoning to explain it in concluding (Sarti, 2019). So, natural science (IPA) is the science that teaches about the entire universe both about objects and living things that are obtained scientifically.

In applying the 2013 curriculum it is not just intelligence and ability or expertise, but horizontally and vertically. The nature or behavior of students must also be developed in every subject to improve the competitiveness of students in facing the era of globalization (Rustan, Hanifah, \& Kanro, 2018).

Natural Science Learning (IPA) is a field of study that is studied by all levels of education. Therefore the field of science studies is a tool or a very effective place for students to learn various fields of science. From science learning, students can think logically systematically and can apply to their environment. One of the characteristics of natural science learning is that it can be integrated into Islam so that the learning process becomes more meaningful, easy to understand, and can make students who are pious and highly intellectual.

In developing modules, what is meant by integration with Islam is the integration of the Qur'anic verses with science. Alquran is a holy book in Arabic given to the Prophet Muhammad to all humanity (Daming, 2017). Where the Qur'an consists PiJIES: Pedagogik Journal of Islamic Elementary School 
of several surahs and several verses, both long and short ones. Verses are some of the holy verses of Allah who are in a surah in the Qur'an. Surah is a collection of several Qur'anic verses that have a beginning and an end (Daming, 2017). Al-Qur'an was revealed by carrying two objectives namely as evidence that what was delivered by the Prophet is a miracle, as a guide or guidance for all people in the world and the hereafter (Awaliah, 2014). Therefore, the introduction of the verses of the Qur'an to students is very necessary from an early age starting from simple things that students often encounter in their environment.

In this study, the material used to develop integrated science teaching materials of the Qur'an verses is the subject of the five human senses. The five senses are organs or organs that function to find out or feel conditions outside the body. There are five senses in humans, namely the eyes, nose, tongue, ears, and skin (Bustomi, 2010). The functions of the five senses are the eyes as the senses of vision, the ears as the senses of the listener, the tongue as the sense of taste, the nose as the sense of smell, and the skin as the sense of touch (Zainudin, 2015).

This teaching material can teach students about the use of the five senses based on the verses contained in the Qur'an because the descent of the Qur'an is nothing but intended to provide demands for humans in achieving happiness in the life of the world and the hereafter. For that, we need a correct understanding of the use of the five senses based on the verses of the Qur'an so that its implementation does not deviate from the provisions of Allah SWT.

This research is following the stages of the development cycle. This development phase consists of several stages, namely: conducting a study of research findings following product development, then the findings will be developed into a product, then testing the product trials, and making revisions after trials are conducted (Punaji, 2013). The main objective of the research is to develop a prototype of integrated five senses teaching materials in the $\mathrm{Al}$ Qur'an verses and to find out the level of effectiveness of the integrated five senses teaching materials on the learning outcomes of students.

\section{Method}


Researchers conduct research types of Research \& Development (R\&D). To make products in the form of modules, the model used is the $4 \mathrm{D}$ development model. The $4 \mathrm{D}$ development research model consists of several stages that need to be carried out namely, defining, designing, developing, and disseminating. Data collection techniques in this study are observation, documentation, and validation. The data analyzed are 1 . Analysis of the validity of teaching materials and instruments, to test their validity using the Aiken's formula. 2. Analysis of the results of the observation sheet of student activities. Data or results that have been collected through instruments used are then analyzed by descriptive statistics and directed to the validity and effectiveness of integrated modules of the verses of the Qur'an.

\section{Result}

The Prototype of Teaching Material of Integrated Five Senses Materials Verses of Valid Qur'an a. Design of teaching materials

The choice of format in making the module integrated with the verses of the Qur'an includes material five senses. The source of the material comes from the teacher's book and the students' book class 1 theme 1 (myself) revised edition 2017 as well as references from the internet.

The stage or structure intended in this teaching material is the elaboration of the components of the learning module of the five senses that are integrated with the verses of the Qur'an for the implementation of teaching and learning in class I SDN 01 Lalebbata Palopo. The explanation referred to as follows: 


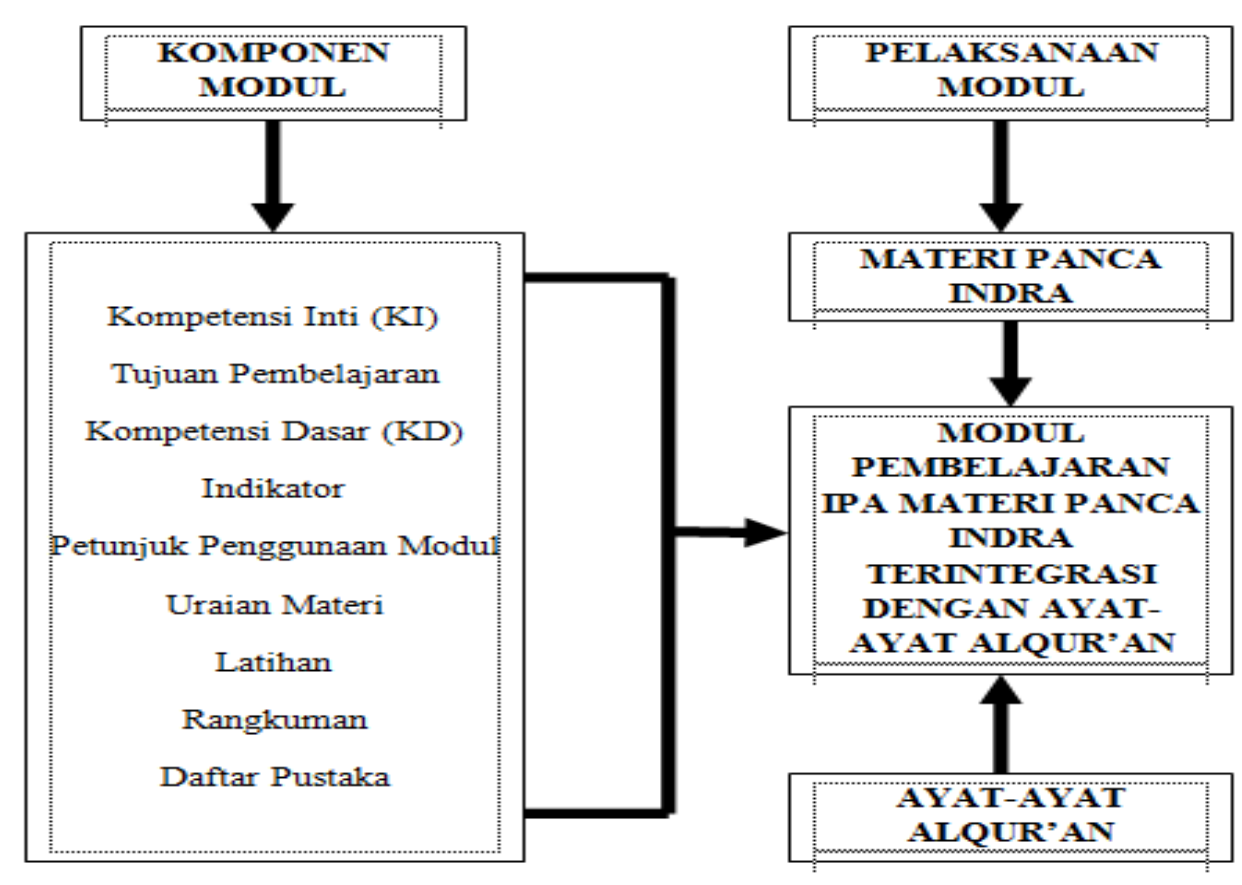

Figure 1. Description of Module Components of the Five Senses Integrated with Al-Qur'an verses

The following is the design format (prototype) of teaching material that has been declared valid after validating from several experts:

\section{1) Cover}

The cover or cover is made as attractive as possible to attract the reader's attention to find out the contents in the module. The module cover consists of the name of the compiler (Mutmainna), the module title is the integrated five senses module of the Qur'anic verses, used for first-grade students of SD / MI semester 1, the cover image is adjusted to the material.

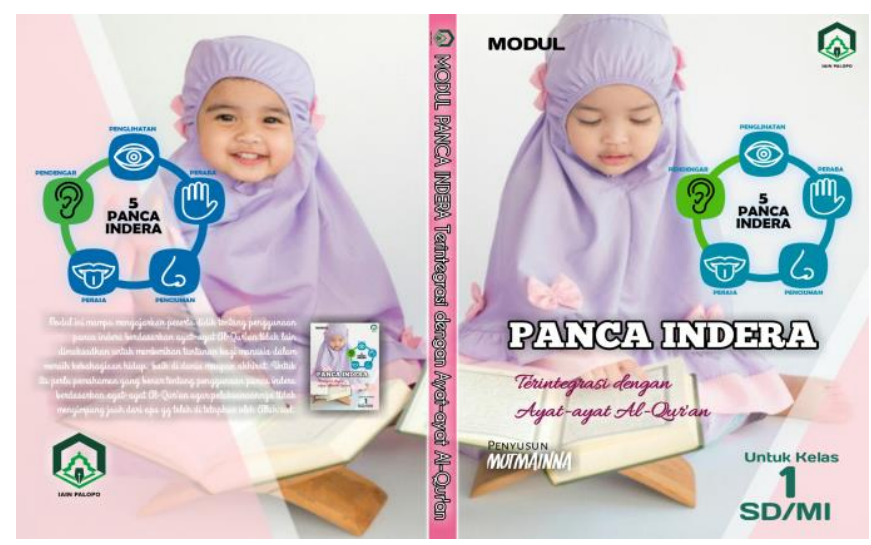

Figure 2. Book cover

PiJIES: Pedagogik Journal of Islamic Elementary School 
2) Preface

It is a series of words about the module compiler's biodata, the author's wishes, and thanks for the various parties helping the writer when making the module.

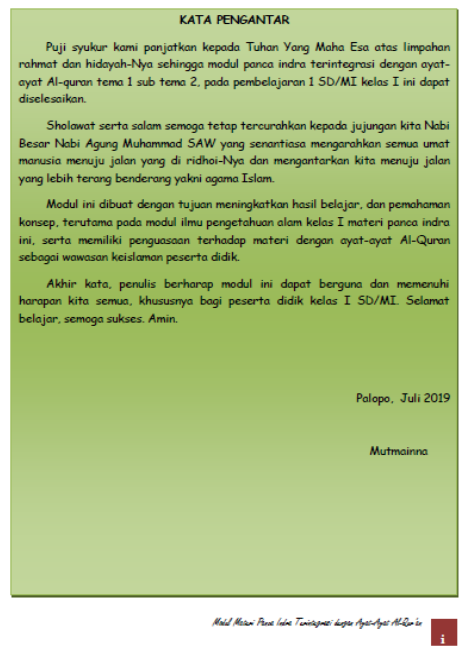

Figure 3. Preface

3) Table of Contents

There is a module content that refers to the module page so that it will make it easier for students to get the contents of the module that they want to see to read.

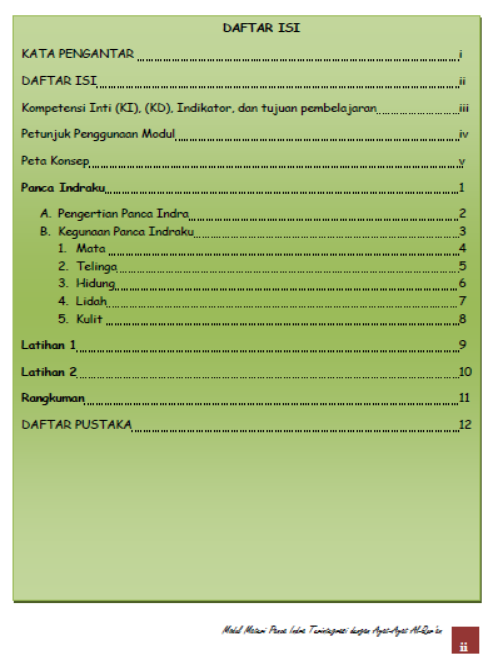

Figure 4. Table of Content 
4) $\mathrm{KI}, \mathrm{KD}$, Indicator, and Learning Objectives

It contains several things to be achieved in learning.

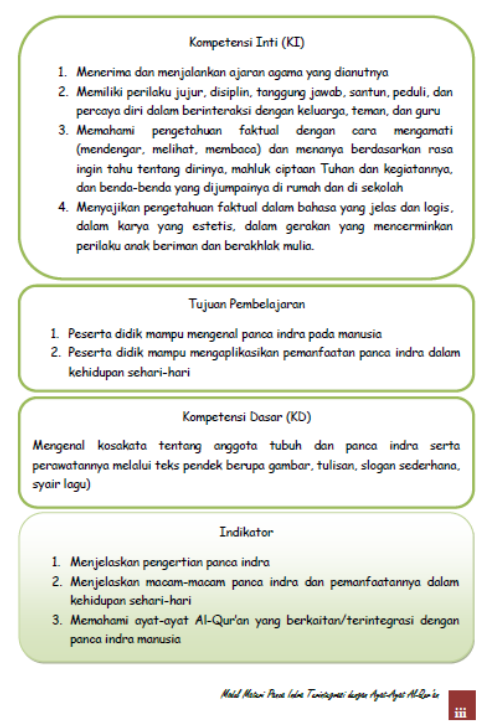

Figure 5. KI, KD, Indicator, and Learning Objectives

5) Module Usage Instructions

It contains how to use modules. Here there are two instructions for using the module including those for teachers and students.

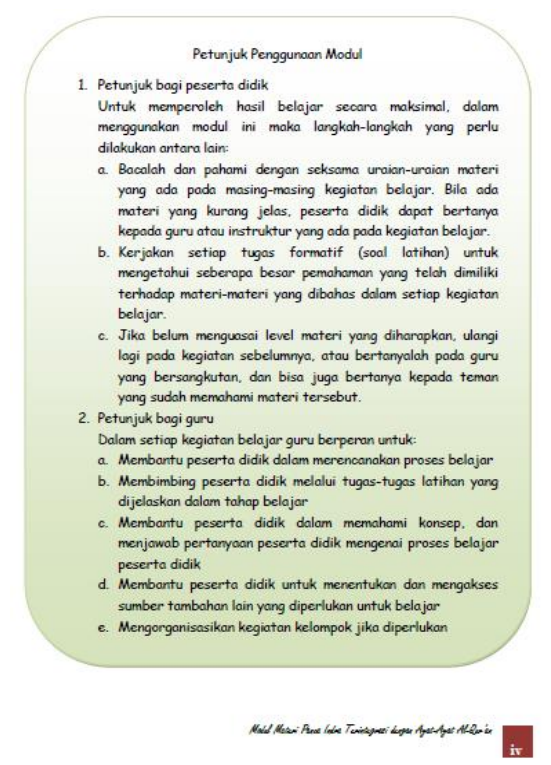

Figure 6. Module Usage Instructions 
6) Concept Maps

The concept map is a chart of the overall concept mapping on the contents of the module made by researchers to make it easier for students to know specifically the contents of the module.
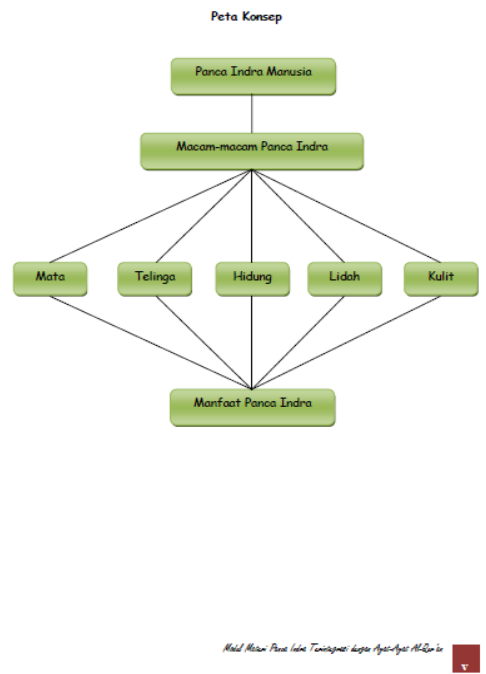

Figure 7. Concept Maps

7) Introduction to Material

Researchers use introductory material in the form of comic stories that discuss the five senses. Its function is to stimulate students so that they learn to use the module.

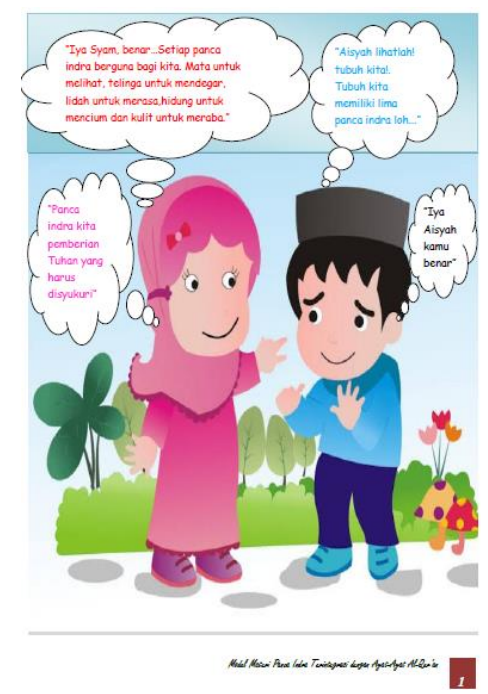

Gambar 8. Introduction to Material 
8) Module content

The module contents contain the five senses that discuss the meaning of the five senses, and the various senses and their functions. The various senses are explained by integrating Qur'anic verses. The Qur'anic verses in the module are QS AlBalad (90): 8 describes the eyes, QS Al-Baqarah (2): 7 describes the ears, QS Nose (5): 45 describes the nose, QS Al-Balad (90): 9 describes the tongue, and QS Al-Anbiya (21): 69 describes the skin.
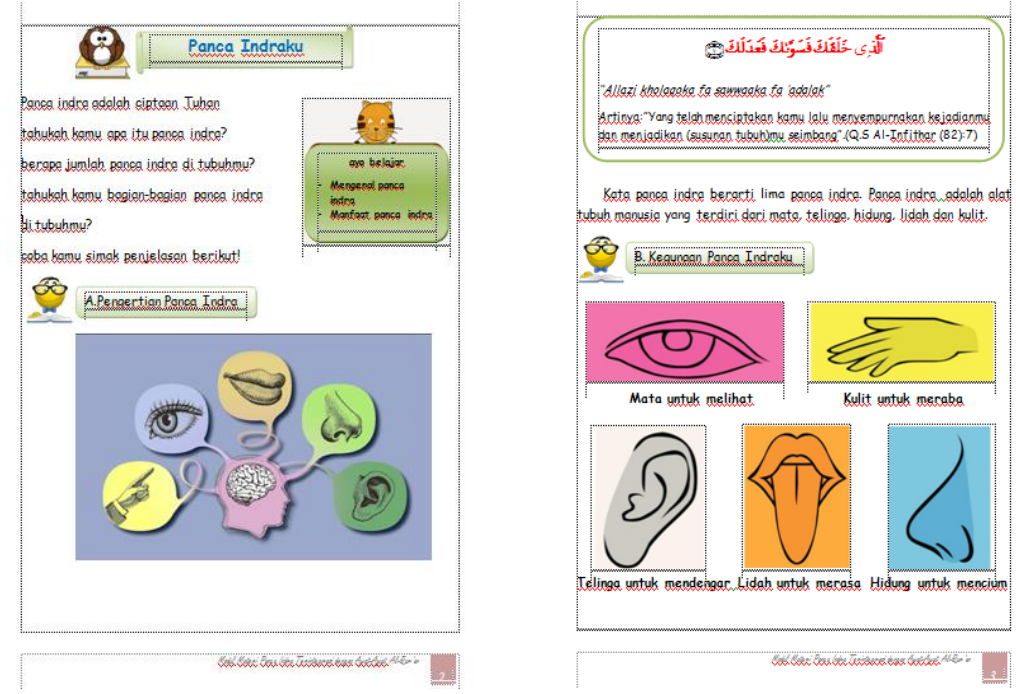

Figure 9. Module content

\section{9) Practice Questions}

Practice questions are used in modules so that they can know the level of understanding of students when studying modules. Researchers create exercises with a level of complexity that is appropriate for elementary school children. There are two practice questions made by researchers, namely, exercise 1 and exercise 2 . 

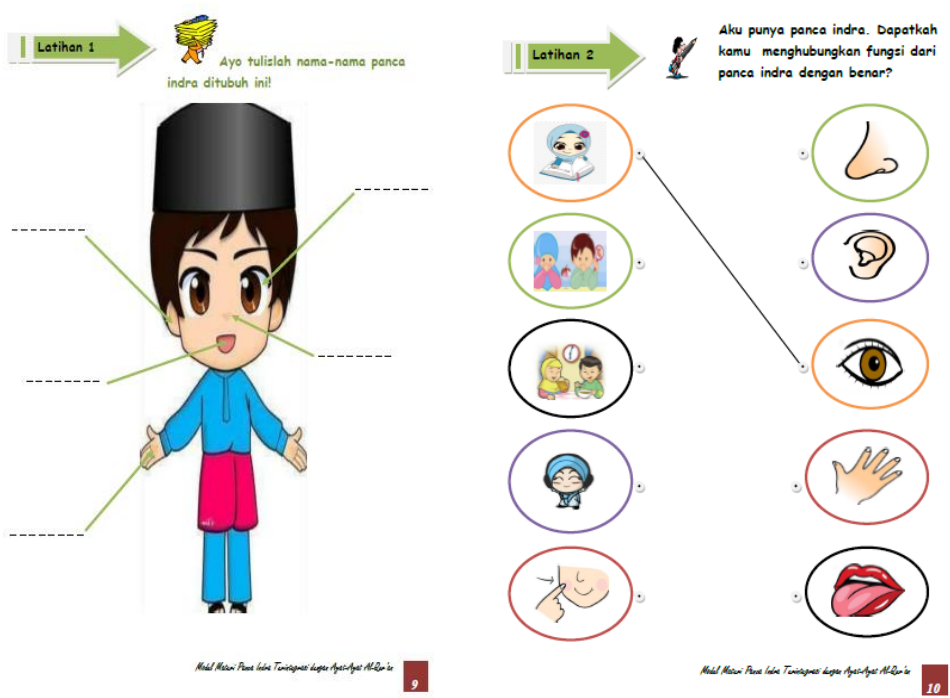

Figure 10. Practice questions

10) Summary

The author makes a summary of the abbreviations of the material described.

This material abbreviation is explained at the end of the material in the module.

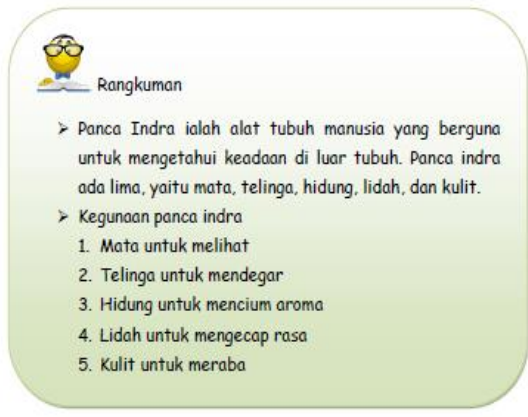

Figure 11. Summary

\section{b. Expert Validation}

One of the main criteria to determine whether or not the proper use of the developed module is the result of validation by experts. The results of the recapitulation of the validity of teaching materials in the form of integrated five senses modules of the Qur'anic verses from three validators can explain that the value of $\mathrm{V}$ (Aikens) is obtained from the formula $V=\frac{6}{[3(4-1)]}=0,67$ as well as the construction team and so on. Aikens coefficient value of $0-1$ coefficient of 1 item and others are PiJIES: Pedagogik Journal of Islamic Elementary School 
considered to have adequate content validity (valid). If seen from the overall aspects of teaching materials meet the validity criteria with valid categories.

The Level of Effectiveness of the Integrated Five-Sense Material Verses of the Qur'anic Verses on Student Learning Outcomes

To know the level of effectiveness of the integrated five senses teaching material with the verses of the Qur'an to the learning outcomes of students, researchers use observation sheets of activities or activities of students. As for the observer, the class I teacher B. Observer will observe and assess the activities of the learning of the five senses. Observation is used by seeing and noting something important when learning. To find out the results of the relative frequency (percentage figures) on each number (item) of the observation sheet the following cumulative frequency formula is used $P=\frac{27}{29} \times 100=93,10 \%$ then declared to be very effective in the excellent category.

\section{Discussion}

The prototype of Teaching Material of Integrated Five Senses Materials Valid Qur'an Verses

Based on the needs analysis conducted, it is known that natural science learning especially the five senses material has not yet reached KKM, the learning resources used are still limited to textbooks and there is no integrated teaching material in the verses of the Qur'an. The characteristic of the module developed is that the material of the five senses is directly related to the verses in the Qur'an that are appropriate. This module was developed by adjusting the module components, the five senses material, and the corresponding Qur'anic verses.

Modules that have been developed can be used during the learning process when it has been validated. Validation is done to determine the level of eligibility of the module to be applied in class. In line with Azwar's opinion, validation is carried out to determine the extent of the validity of the instrument in carrying out its size function (Prasetyo, 2006). Measuring instruments are said to have high validity results if the instrument can carry out its size function and vice versa if the test produces irrelevant data then the test has low validity.

\section{PiJIES: Pedagogik Journal of Islamic Elementary School}


Teaching material will be said to be valid if the teaching material is consistent in each preparation of the module sections commonly referred to as construct validity. The material can be called valid if the learning objectives, learning materials, and module content are appropriate. Teaching material is said to be valid if it meets the validity test criteria that have been carried out before being tested to find out the intended purpose. So it can be said that whether an instrument is valid or not can be seen from whether or not the desired instrument has the right measurement objectives (Ahmad, 2005).

Following the observations and theories that have been explained, teaching materials made are in the valid category, because it can be seen from several aspects of the module that have been made showing an average of 0.67 . Based on criteria that have been made previously namely the validity value that is in the range $0.6-0.8$ is categorized as high validity (Yusup, 2018). Thus teaching materials can be used in class and then their effectiveness is measured.

The Level of Effectiveness of the Integrated Five Senses Module Material of the Qur'anic Verses on Student Learning Outcomes

The module developed by the researcher is an integrated module of the five senses of the verses of the Qur'an which will be tested for effectiveness by observing or observing the activities of students through the observation sheet. After going through the validation stage, what will be done next is to test the finished module to determine its effectiveness. Trials are conducted to obtain information about the module whether it is more efficient and effective when compared to the old module or the other (Sugiyono, 2014).

Based on the analysis of effectiveness test data using statistical analysis obtained $93.10 \%$ of observations or observations of student activities. This can prove that the teaching material that has been developed can improve student learning outcomes because the level of effectiveness is declared very effective with very good categories. The results of this study are in line with research conducted by (Riwu, Laksana, \& Dhiu, 2018) which shows that the development of teaching materials that are appropriate to the subject matter will make it easier for students to understand the material presented and make learning more interesting and enjoyable. Furthermore, 
(Achmad, 2017) states that there is a positive and significant relationship between the development of teaching materials and learning media on student learning outcomes. This is because learning outcomes are obtained from the learning process that has been done (Ari, 2016).

\section{Conclusion}

The development of a prototype of five senses teaching materials integrated with the verses of the Qur'an, carried out with various models of $4 \mathrm{D}$ development. Data recapitulation of the validity of teaching materials can be obtained a value of 0.67 as well as the construction team and so on, so that in terms of all aspects of the value included in the category. Meanwhile, for the level of effectiveness of the integrated five senses material module of the Qur'an verses, following the analysis of competency test data using statistical analysis obtained $93.10 \%$ the percentage of results of observation or interaction of students. It can be agreed that the module developed was able to improve student learning outcomes because the level of effectiveness was stated to be very effective in the excellent category.

\section{References}

Achmad, A. (2017). Hubungan Pengembangan Bahan Ajar dan Media Pembelajaran dengan Hasil Blajar Siswa pada Mata Pelajaran Pendidikan Agama Islam di Sekolah Dasar Negeri Kecamatan Sungai Kunjang. Syamil, 5(1), 59-73.

Ahmad, M. D. (2005). Validitas Konstruk Skala Afek. 2(1).

Aprilia, A. (2018). Pemahaman Konsep Perubahan Sifat Benda Pada Mata Pelajaran IPA Melalui Metode Eksperimen. Pedagogik Journal of Islamic Elementary School, 1(1), 11-22. https:/ / doi.org/10.24256/ pijies.v1i1.339

Ari, I. (2016). Efektivitas Mathmagic Dalam Peningkatan Hasil Belajar Matematika. Jurnal Formatif, 6(1).

Arum, T. S., \& Wahyudi, W. (2016). Pengembangan Modul Pembelajaran Tematik Integratif Subtema Hubungan Makhluk Hidup dalam Ekosistem Pendekatan Saintifik untuk Kelas 5 SD. Scholaria: Jurnal Pendidikan Dan Kebudayaan, 6(3), 239250. 
Awaliah, M. (2014). Pengaruh Al-Qur'an dan Hadits Terhadap Bahasa Arab. Jurnal AlHikmah, 15(1).

Bustomi, A. Y. (2010). Aplikasi Pembelajaran Panca Indra Pada Manusia Berbasis Android. Telematika, 3(1).

Daming, M. (2017). Keagungan Al-Qur'an. Makassar: Pustaka Al-Zikra.

Daryanto, \& Aris, D. (2014). Pengembangan Perangkat Pembelajaran (Silabus, RPP, PHB, Bahan Ajar). Yogyakarta: Penerbit Gava Media.

Hamid, D. (2012). Kemampuan dasar mengajar landasan konsep dan implementasi. Bandung: Alfabeta.

Indonesia, P. R. (2003). Undang-undang Republik Indonesia nomor 20 tahun 2003 tentang sistem pendidikan nasional. Jakarta: Pemerintah Republik Indonesia.

Lady, A. (2013). Pengembangan Modul IPA dengan Menggunakan Siklus Belajar (5E) Materi Struktur dan Fungsi Jaringan pada Tumbuhan. Universitas Muhammadiyah Malang.

Parmin, \& Peniati, E. (2012). Pengembangan Modul Mata Kuliah Strategi Belajar IPA Berbasis Hasil Penelitian Pembelajaran. Jurnal Pendidikan IPA Indonesia, 1(1).

Prasetyo, W. B. (2006). Reliabilitas dan Validitas Konstruk Skala Konsep Diri Untuk Mahasiswa Indonesia. Jurnal Psikologi Universitas Diponegoro, 3(1).

Riwu, I. U., Laksana, D. N. L., \& Dhiu, K. D. (2018). Pengembangan Bahan Ajar Elektronik Bermuatan Multimedia Pada Tema Peduli Dasar Kelas Iv Di Kabupaten Ngada. Journal of Education Technology, 2(2), 56-64.

Rustan, E., Hanifah, N., \& Kanro, B. (2018). De-radicalization in the Implementation of Islamic Education Curriculum in SMA Masamba South Sulawesi. Dinamika Ilmu, 18(2), 271-283. https://doi.org/10.21093/di.v18i2.1338

Sarti. (2019). Penerapan Model Cooperative Script Dalam Pembelajaran IPA Pokok Bahasan Gaya Untuk Meningkatkan Hasil Belajar Pada Siswa Kelas IV SDN 097 Rompu Kabupaten Luwu Utara. Pedagogik Journal of Islamic Elementary School, 1(2).

Setyowati, R., Parmin, P., \& Widiyatmoko, A. (2013). Pengembangan Modul IPA Berkarakter Peduli Lingkungan Tema Polusi Sebagai Bahan Ajar Siswa SMKN 11 Semarang. Unnes Science Education Journal, 2(2).

Sugiyono. (2014). Metode Penelitian Kuantitatif Kualitatif dan RED. Bandung: Alfabeta. 
Yusup, F. (2018). Uji Validitas dan Reliabilitas Instrumen Penelitian Kuantitatif. Jurnal Tarbiyah: Jurnal Ilmiah Kependidikan, 7(1), 17-23. https://doi.org/10.18592/tarbiyah.v7i1.2100

Zainudin, A. (2015). Indra Sebagai Alat untuk Belajar Bagi Manusia Berdasarkan Q.S AnNahl Ayat 78 dan Q.S Al-A'raf Ayat 179. UNISNU Jepara. 